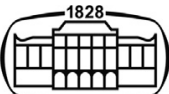

AKADÉMIAI KIADÓ

International Review of Applied Sciences and Engineering

$11(2020)$ 1, 34-42

DOI:

$10.1556 / 1848.2020 .00005$

(c) 2020 The Authors

\title{
Optimization by RSM on rotary friction welding of AA1100 aluminum alloy and mild steel
}

\author{
F. KHALFALLAH ${ }^{1,2 *} \odot$, Z. BOUMERZOUG ${ }^{1}$, S. RAJAKUMAR ${ }^{3}$ \\ and E. RAOUACHE ${ }^{4}$ \\ ${ }^{1}$ Department of Mechanical Engineering, University of Biskra, B.P. 145, Biskra, Algeria \\ ${ }^{2}$ Department of Physics, Faculty of Science, University of M'sila, M'sila, 28000, Algeria \\ ${ }^{3}$ Centre for Materials Joining \& Research, Department of Manufacturing Engineering, Annamalai \\ University, India \\ ${ }^{4}$ Civil Engineering Department, University of Bordj Bou Arreridj, Algeria
}

Received: January 31, 2019 • Accepted: March 20, 2019

Published online: April 18, 2020

\section{ORIGINAL RESEARCH PAPER}

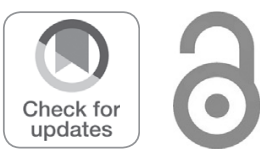

\begin{abstract}
The objective of this work is to investigate the rotary friction welding of AA1100 aluminum alloy with mild steel, and to optimize the welding parameters of these dissimilar materials, such as friction pressure/time, forging pressure/time and rotational speed. The optimization of the welding parameters was deduced by applying Response Surface Methodology (RSM). An empirical relationship was also applied to predict the welding parameters. Tensile test and micro-hardness measurements were used to determine the mechanical properties of the welded joints. Some joints were analyzed by scanning electron microscopy (SEM) and energy dispersive X-ray spectroscopy (EDS) in order to investigate the formation of intermetallic compound (IMC) layer at the weld interface. Experimentally, the tensile strength of the weld increases with increasing the forging pressure/time, while the low level of forging pressure/time allows the formation of an IMC layer which reduces the tensile strength of the weld.
\end{abstract}

\section{KEYWORDS}

optimization, response surface methodology, rotary friction welding, AA1100 aluminum alloy, mild steel

\section{INTRODUCTION}

Today, the joining of aluminum alloys with steel is widely used in the automotive industry, since reducing the weight of vehicles is one of the effective measures to save energy and preserve the environment. The interest to this combination of materials is mainly due to the light weight, high heat conductivity and corrosion resistance characteristics of aluminum alloys that compliment well with the high strength and toughness of steel [1].

In general, the joints of metals are made by welding processes. In welding of aluminum alloys to steel, the formation of an intermetallic compound (IMC) is necessary to achieve an effective bond between the two metals. However, in the case of fusion welding steel/ aluminum, the excessive formation of IMC, in particular, the Al-rich phases, degrades the joint strength [2]. To avoid the formation of such brittle IMC, some technical conditions should be satisfied, i.e., welding should occur in the solid state at low temperature and in short time [3]. The friction welding (FW) is a solid state welding process; it is one of the most suitable methods for joining aluminum alloys to steel [4]. Rotary Friction Welding (RFW) is the most commonly used method in friction welding. It can be applied in two ways: continuous drive friction welding and inertia friction welding [5]. However, the RFW process has a limitation of use, since it cannot be used for welding parts with a non-circular crosssection [6].

* Corresponding author. Department of Mechanical Engineering, University of Biskra, B.P. 145, Biskra, Algeria E-mail: fa_fares@yahoo.fr, fares. khalfallah@univ-msila.dz. 
In continuous drive method, a rotating sample is pressed against a stationary sample as shown in Fig. 1(a and b). The friction at the interface generates the welding heat, which upset the samples (Fig. 1c). Finally, the rotation stops and a forging pressure is introduced to achieve the bonding (Fig. 1d) [7, 8].

As it is reported, several welding parameters affect the quality of friction welds, such as friction time, forging time, friction pressure, forging pressure, and rotational speed [ 9 , 10]. Figure 2 shows the parameters and the phases of continuous drive friction welding. In general, RFW consists of two phases: a friction phase to generate the necessary heat and a forging phase to consolidate the weld [11].

According to the literature, some researchers had investigated the friction welding of aluminum alloys with steel [12-16]. Fukumoto et al. [13, 14] carried out a rotary friction welding of AISI 304 austenitic-stainless steel with aluminum and proved that the friction welding process was very efficient in the welding of these dissimilar materials. They reported that strength increase as the friction time increase, but a longer friction time caused the excess formation of $\mathrm{Fe}-\mathrm{Al}$ based IMC layer at the friction weld interface, which decreases the strength of joint. Sahin [17] studied also the rotary friction welding of AISI 304 austenitic-stainless steel with aluminum. He has shown that

(a)

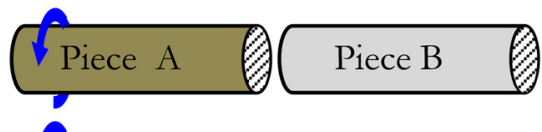

(b)

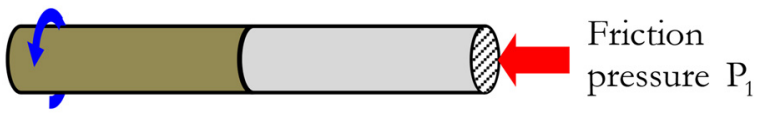

(c)

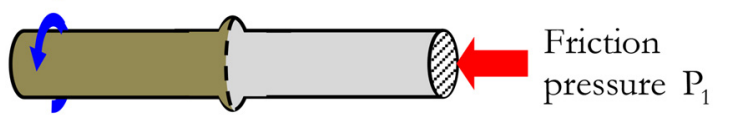

(d)

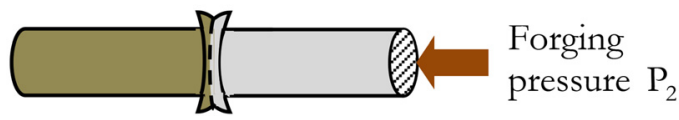

Figure 1. Rotary friction welding process

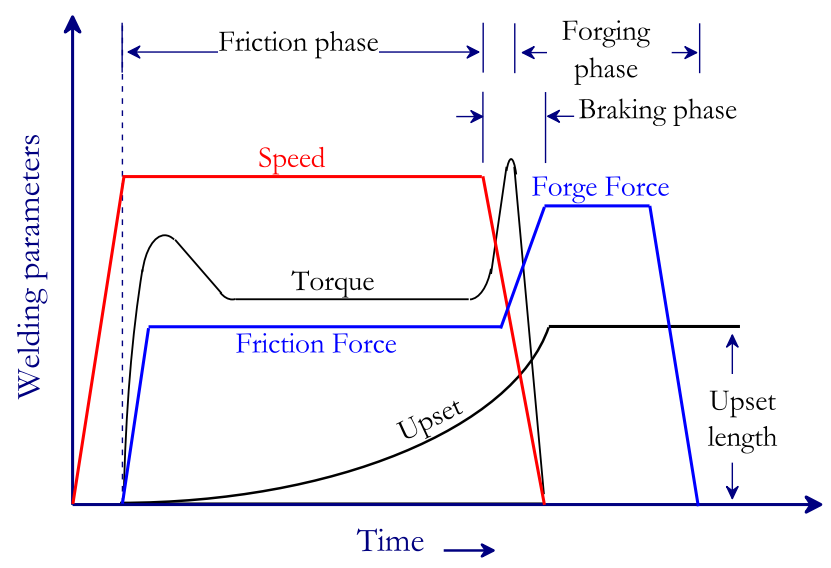

Figure 2. Parameters and phases of continuous drive friction welding [6] friction time, friction pressure, and forging pressure have a strong effect on tensile strength, microstructures, and hardness of joints.

In addition, Alves et al. [18] studied the rotary friction welding of AA 1050 aluminum alloy to AISI 304 austeniticstainless steel and showed that the strength of the joints varied with friction time and other welding parameters. Meshram et al. [19] developed a rotary friction welding of AISI 4340 austenitic-stainless steel with AA6061 aluminum alloy, using a silver interlayer as a diffusion barrier for Fe. They found that silver interlayer avoids the formation of the brittle IMC layer, and increases the tensile strength of welds.

However, Wan et al. [20] investigated the effects of friction time on microstructure characteristics and mechanical properties of friction welding AISI 316L steel to AA6061 aluminum alloy. They machined a welding groove of $15^{\circ}$ on the end of steel part to help control the growth of IMC layers. The thickness of IMC layers increased with elevated friction time, while the machining of the welding groove reduced the IMC layer thickness. The tensile strength reached 166.32 $\mathrm{MPa}$ in the case of the welding groove; it was higher than that of the joint without welding groove [20].

In addition to the experimental investigation, new statistical methods were applied to determine the optimum parameters, i.e., to reduce the number of the experiments [21-23]. In this approach, Paventhan et al. [21] used Response Surface Methodology (RSM) as a statistical approach to optimize the welding parameters for achieving an optimum tensile strength of AA6082 alloy to AISI 304 austenitic stainless steel joints. Pachal et al. [22] used Taguchi Experiment Design Technique to optimize welding parameters for maximizing tensile strength of friction welding AA $6061 \mathrm{Al}$ alloy to AISI 304. Mathiazhagan et al. [23] developed an empirical relationship between the welding parameters and the tensile property of the welded AA $6063 \mathrm{Al}$ alloy and AISI 304, using the RSM technique and the Adaptive Neuro-Fuzzy Inference System (ANFIS) technique.

In this study, an attempt was made to optimize friction welding parameters for achieving optimum mechanical properties such as tensile strength and hardness of welded AA1100 aluminum alloy to mild steel, using the Response Surface Methodology (RSM) and statistical software as Design Expert. In addition, some joints were characterized by scanning electron microscopy (SEM) and energy dispersive X-ray spectroscopy (EDS).

\section{EXPERIMENTAL PROCEDURE}

\subsection{Welding process}

The materials used in this experimental work were aluminum AA1100 and mild steel. They were cylindrical rods with $12 \mathrm{~mm}$ in diameter and $70 \mathrm{~mm}$ in length, as shown in Fig. 3. Table 1 presents the chemical compositions of these two dissimilar materials determined by $\mathrm{X}$-ray fluorescence (XRF) technique. 


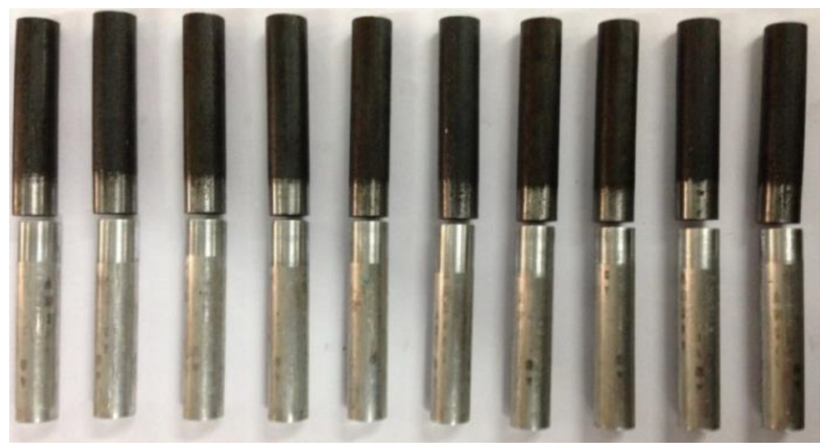

Figure 3. Macrographic view of AA1100 aluminum alloy and mild steel specimens before welding

The welding process was carried out using a continuous drive friction welding machine (Rexroth, R.V. Machine tools) as shown in Fig. 4. The rotating workpiece is the mild steel rod, while the non-rotating work piece is the aluminum rod. Before the welding process, the ends of samples were polished and cleaned to reduce the effect of contaminants, especially grease, which can affect the quality of joints.

\subsection{Response surface methodology (RSM)}

The effect of friction welding parameters on the properties of the joints can be carried out using the Response Surface Methodology (RSM). RSM is a design of experiment (DOE) technique which is used for prediction or optimization. It is a statistical approach employed for analyzing and developing the effect of different independent variables (named the factors $\boldsymbol{x}_{\boldsymbol{i}}$ ) on a dependent variable (response). The objective is to optimize this response [24,25]. The advantage of using RSM or other DOE techniques is to reduce the number of experiments.

In this study, the optimization of welding parameters that influence the tensile strength (TS) and micro-hardness $(\mathrm{MH})$, was performed by RSM technique, based on selecting three-factors and five-levels factorial design matrix. The three welding parameters selected in this work are:

- Friction pressure $/$ time $=\frac{\text { Friction pressure }}{\text { Friction time }}$

- Forging pressure $/$ time $=\frac{\text { Forging pressure }}{\text { Forging time }}$

- Rotational speed.

The five chosen values for each process parameter are listed in Table 2. The upper and lower levels were coded as +2 and -2 , respectively, and the coded value for each level can be calculated from the following relationship:

$$
X_{i}=2 \dot{s} \frac{\left[2 X-\left(X_{\max }+X_{\min }\right)\right]}{\left(X_{\max }-X_{\min }\right)}
$$

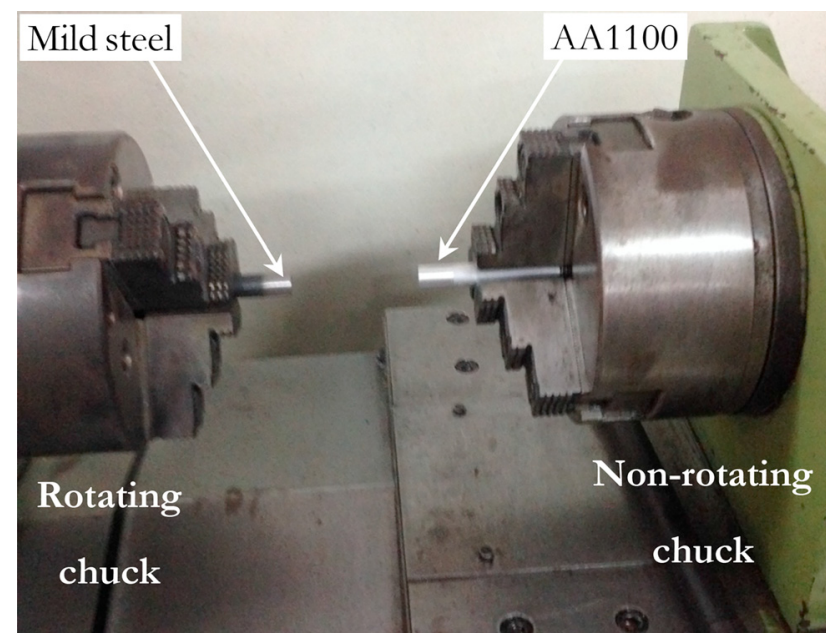

Figure 4. General view of a part of the RFW machine

where $X_{i}$ is the required coded value of a variable and $X$ is any value of the variable from the lowest level $X_{\min }$ to the highest level $X_{\max }[21,26]$.

The welding experiments were performed using the parameters dictated by the design matrix presented in Table 3.

The welded samples (Fig. 5a), three for each experiment, were machined and prepared for mechanical and microstructural testing. For the tensile test, the welded specimens are prepared according to ASTM standards (Fig. 5b). After that, they were tested using a $100 \mathrm{kN}$, servo controlled universal testing machine (Make: FIE-Bluestar, Model: UNITEK 94100) with a crosshead speed of $0.5 \mathrm{~mm} / \mathrm{min}$.

For micro-hardness measurements and microstructural analysis, the welded specimens were sectioned, polished, and etched with Keller and Nital reagents. The micro-hardness measurements were recorded using a micro-hardness tester (Make: Shimadzu, Model: HMV-2T) at $200 \mathrm{~g}$ load at three different locations in the welded joint. The microstructure of some samples was observed using a scanning electron microscopy (SEM) (Make: JEOL, Model: JSM-6610LV) coupled with energy dispersive X-ray spectroscopy (EDS).

\subsection{Developing of empirical relationship}

By applying RSM, an empirical relationship between the welding parameters and output response can be established, and used for reach an optimum response value.

Generally, for our study, a second-order polynomial equation is used in the form:

$$
y=b_{0}+\sum_{i=1}^{n} b_{i} X_{i}+\sum_{i=1}^{n} b_{i i} X_{i}^{2}+\sum \sum_{i<j} b_{i j} X_{i} X_{j}+\varepsilon
$$

Table 1. The chemical composition of aluminum and steel rods (wt\%)

\begin{tabular}{llccccccccc}
\hline Materials & $\mathrm{C}$ & $\mathrm{Si}$ & $\mathrm{S}$ & $\mathrm{P}$ & $\mathrm{Mn}$ & $\mathrm{Cu}$ & $\mathrm{Mg}$ & $\mathrm{Zn}$ & $\mathrm{Fe}$ & $\mathrm{Al}$ \\
\hline AA 1100 & - & 0.57 & - & 0.04 & - & 0.01 & 0.53 & 0.02 & 0.23 & 98.6 \\
Mild Steel & 0.39 & 0.28 & 0.03 & 0.03 & 0.9 & 0.14 & - & - & 98.2 & 0.03 \\
\hline
\end{tabular}


Table 2. Friction welding parameters and their levels for the central composite design (CCD)

\begin{tabular}{lllccccc}
\hline & & & \multicolumn{3}{c}{ Level } \\
\cline { 4 - 8 } Parameter & Notation & Unit & -1.414 & -1 & 0 & +1 & +1.414 \\
\hline Friction pressure/time & $\mathrm{A}$ & $\mathrm{MPa} / \mathrm{s}$ & 3.62 & 4.08 & 5.20 & 6.31 & 6.77 \\
Forging pressure/time & $\mathrm{B}$ & $\mathrm{MPa} / \mathrm{s}$ & 16.79 & 21.54 & 33.01 & 44.47 & 49.22 \\
Rotational speed & $\mathrm{C}$ & $\mathrm{rpm}$ & 900 & 930 & 1,000 & 1,070 & 1,100 \\
\hline
\end{tabular}

Table 3. Designed matrix and experimental results

\begin{tabular}{|c|c|c|c|c|c|c|c|c|}
\hline \multirow[b]{2}{*}{ Expt. no. } & \multicolumn{3}{|c|}{ Coded Values } & \multicolumn{3}{|c|}{ Actual values } & \multicolumn{2}{|c|}{ Results } \\
\hline & A & $\mathrm{B}$ & $\mathrm{C}$ & A & B & $\mathrm{C}$ & TS (MPa) & $\begin{array}{l}\mathrm{MH} \\
(\mathrm{Hv})\end{array}$ \\
\hline 1 & +1 & +1 & -1 & 6.31 & 44.47 & 930 & 167.44 & 290.5 \\
\hline 2 & +1 & -1 & +1 & 6.31 & 21.54 & 1,070 & 151.26 & 299 \\
\hline 3 & -1 & +1 & +1 & 4.08 & 44.47 & 1,070 & 161.56 & 346.33 \\
\hline 4 & -1 & -1 & -1 & 4.08 & 21.54 & 930 & 161.03 & 310.67 \\
\hline 5 & -1.414 & 0 & 0 & 3.62 & 33.01 & 1,000 & 156.01 & 350.5 \\
\hline 6 & +1.414 & 0 & 0 & 6.77 & 33.01 & 1,000 & 171.67 & 266.5 \\
\hline 7 & 0 & -1.414 & 0 & 5.20 & 16.79 & 1,000 & 156.01 & 253.5 \\
\hline 8 & 0 & +1.414 & 0 & 5.20 & 49.22 & 1,000 & 178.46 & 324 \\
\hline 9 & 0 & 0 & -1.414 & 5.20 & 33.01 & 900 & 167.29 & 332 \\
\hline 10 & 0 & 0 & +1.414 & 5.20 & 33.01 & 1,100 & 152.62 & 286 \\
\hline 11 & 0 & 0 & 0 & 5.20 & 33.01 & 1,000 & 174.13 & 288.67 \\
\hline 12 & 0 & 0 & 0 & 5.20 & 33.01 & 1,000 & 174.13 & 288.67 \\
\hline 13 & 0 & 0 & 0 & 5.20 & 33.01 & 1,000 & 174.13 & 288.67 \\
\hline 14 & 0 & 0 & 0 & 5.20 & 33.01 & 1,000 & 174.13 & 288.67 \\
\hline 15 & 0 & 0 & 0 & 5.20 & 33.01 & 1,000 & 174.13 & 288.67 \\
\hline
\end{tabular}
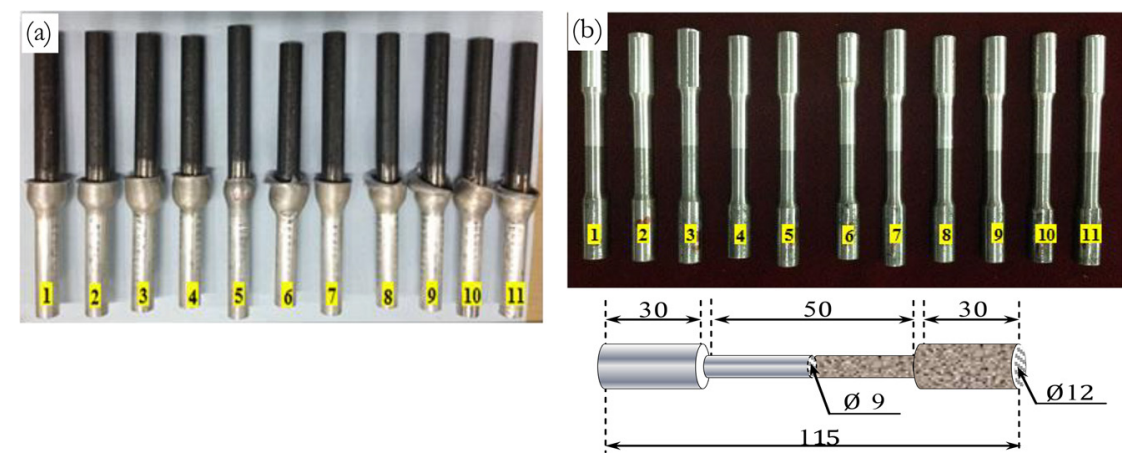

Figure 5. Friction welded samples: (a) Macrographic view ; (b) Tensile testing specimen details (Unit: mm)

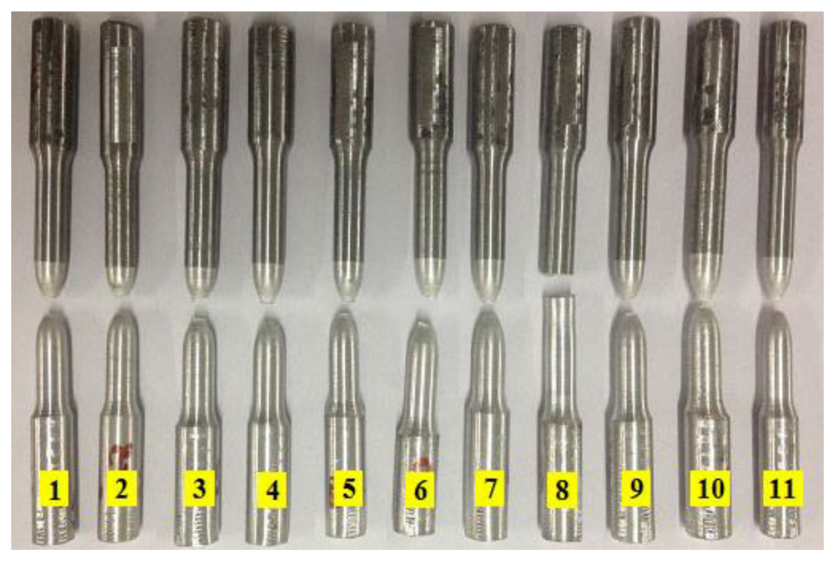

Figure 6. Photograph of samples after tensile test where, $\varepsilon$ represents the noise (error) observed in the response $y$ and $n$ is the factor's number.

In our case, with the use of three factors A, B and C, the selected polynomial could be expressed by:

$$
\begin{aligned}
y= & b_{0}+b_{1} A+b_{2} B+b_{3} C+b_{12} A B+b_{13} A C+b_{23} B C \\
& +b_{11} A^{2} b_{22} B^{2}+b_{33} \dot{s} C^{2}
\end{aligned}
$$

with $b_{0}$ is the average value (intercept) of the response and $b_{1}, b_{2}, b_{3}, \ldots$ and $b_{33}$ are the regression coefficients [27, 28].

The average value and the other regression coefficients were obtained using small central composite design (CCD) technique, with statistical software as Design Expert 7.0. 


\section{RESULTS AND DISCUSSION}

\subsection{Tensile strength testing}

The results of the tensile test are shown in Table 3. The maximum value, $178.46 \mathrm{MPa}$, was recorded in sample 8 , which is prepared at the maximum value of forging pressure/time of $(49.22 \mathrm{MPa} / \mathrm{s})$. Figure 6 shows the specimens after testing. It can be observed that sample 8 shows a brittle rupture while the others show a ductile rupture (necking shape) [29].

\subsection{RSM results}

3.2.1. Significance test of the model. To verify the adequacy of the developed model, an analysis of variance (ANOVA) was performed, and the probability of significance of each coefficient was expressed by "Prob > F."

For our investigation, if the "Prob $>\mathrm{F}$ " values are less than 0.05 , this means that the model terms are significant (the confidence level is 95\%) [28].

The ANOVA for the tensile strength (TS) and microhardness $(\mathrm{MH})$ is given in Table 4. From this table, it can be understood that the developed relationships are adequate for predicting the tensile strength and hardness of friction welded AA1100 Aluminum alloy-Mild steel at 95\% confidence level.

Figure 7 indicates a high degree of correlation between predicted and experimental values for each response, which means that the above model is adequate.

According to the developed model, the empirical relationships for predicting tensile strength and hardness were expressed as follows:

Table 4. Design-expert ANOVA

\begin{tabular}{|c|c|c|c|c|c|c|}
\hline Source & Sum of Squares & $d f$ & Mean square & F-value & $P$-value Prob $>\mathrm{F}$ & \\
\hline \multicolumn{7}{|l|}{ For TS: } \\
\hline Model & 1155.67 & 9 & 128.41 & 123.60 & $<0.0001$ & significant \\
\hline A & 122.62 & 1 & 122.62 & 118.03 & 0.0001 & \\
\hline$B$ & 252.00 & 1 & 252.00 & 242.57 & $<0.0001$ & \\
\hline$C$ & 107.60 & 1 & 107.60 & 103.58 & 0.0002 & \\
\hline Residual & 5.19 & 5 & 1.04 & & & \\
\hline Lack of fit & 5.19 & 1 & 5.19 & & & \\
\hline Pure error & 0 & 4 & 0 & & & \\
\hline Std. deviation & 1.02 & & $R^{2}$ & 0.9955 & & \\
\hline Mean & 166.27 & & Adj. $R^{2}$ & 0.9875 & & \\
\hline CV (\%) & 0.61 & & Pred. $R^{2}$ & 0.5162 & & \\
\hline Press & 561.58 & & Adeq. precision & 34.350 & & \\
\hline \multicolumn{7}{|l|}{ For MH: } \\
\hline A & 3528.00 & 1 & 3528.00 & 1481.48 & $<0.0001$ & \\
\hline$B$ & 2485.13 & 1 & 2485.13 & 1043.56 & $<0.0001$ & \\
\hline$C$ & 1058.00 & 1 & 1058.00 & 444.28 & $<0.0001$ & \\
\hline Residual & 11.91 & 5 & 2.38 & & & \\
\hline Lack of fit & 11.91 & 1 & 11.91 & & & \\
\hline Pure error & 0 & 4 & 0 & & & \\
\hline Std. deviation & 1.54 & & $R^{2}$ & 0.9989 & & \\
\hline Mean & 300.16 & & Adj. $R^{2}$ & 0.9969 & & \\
\hline CV (\%) & 0.51 & & Pred. $R^{2}$ & 0.8788 & & \\
\hline Press & 1287.28 & & Adeq. precision & 76.984 & & \\
\hline
\end{tabular}

(a)

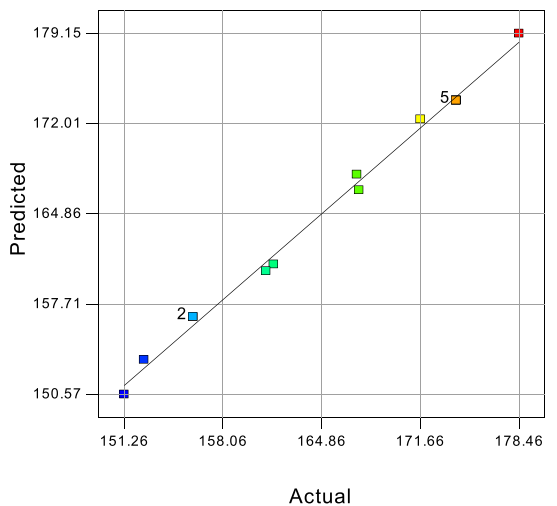

(b)

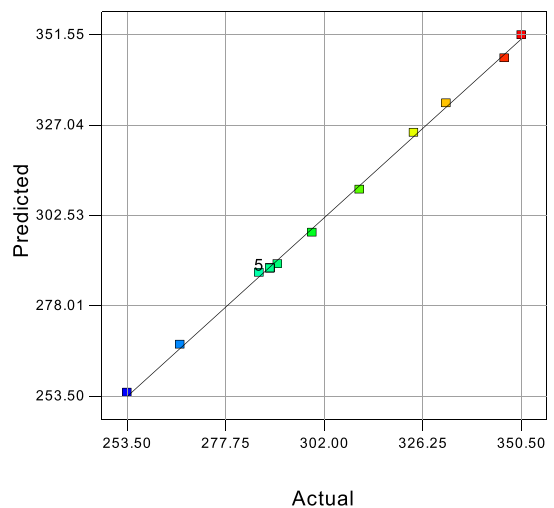

Figure 7. Correlation graph for the response: (a) Tensile strength (TS), (b) Micro-hardness (MH) 
Tensile strength:

$$
\begin{aligned}
T S= & -751.91-0.45 A-5.33 B+2.05 C-0.1 A B \\
& +0.05 A C+8.03 \times 10^{-3} B C-3.76 A^{2} \\
& -0.02 B^{2}-1.32 \times 10^{-3} C^{2}
\end{aligned}
$$

(a) Rotational speed $=1000 \mathrm{rpm}$

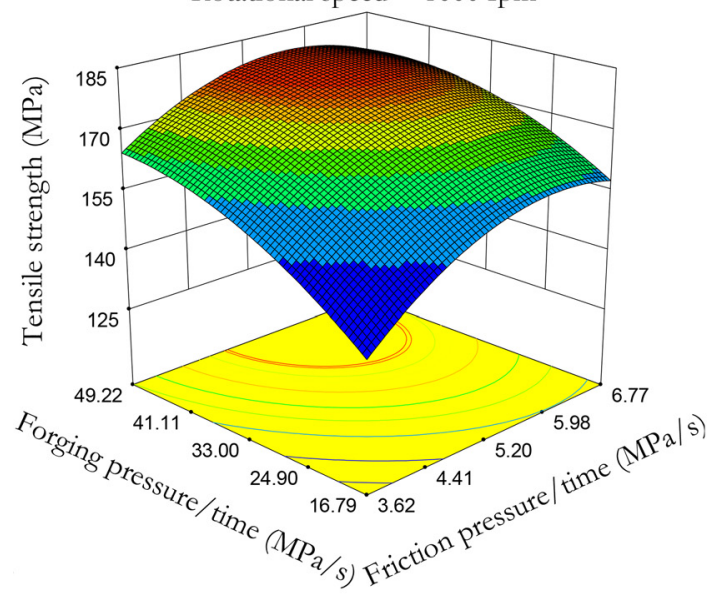

Forging pressure/time $=33,01 \mathrm{MPa} / \mathrm{s}$

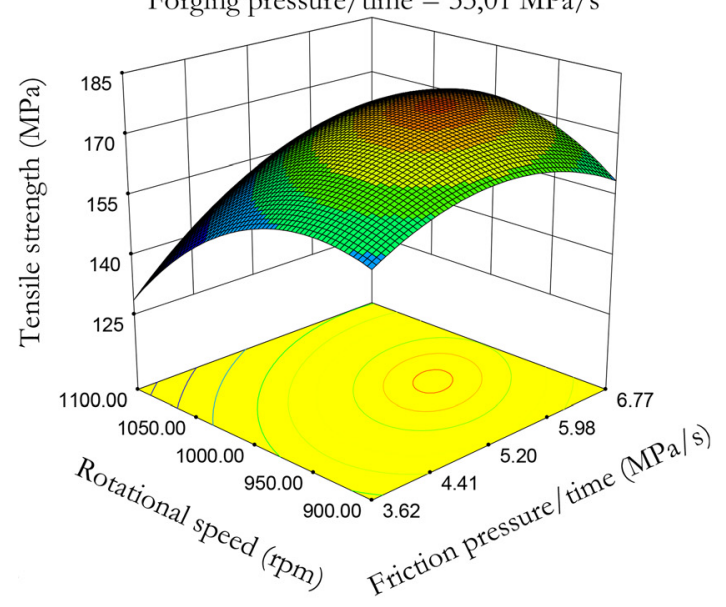

Friction pressure $/$ time $=5,20 \mathrm{MPa} / \mathrm{s}$

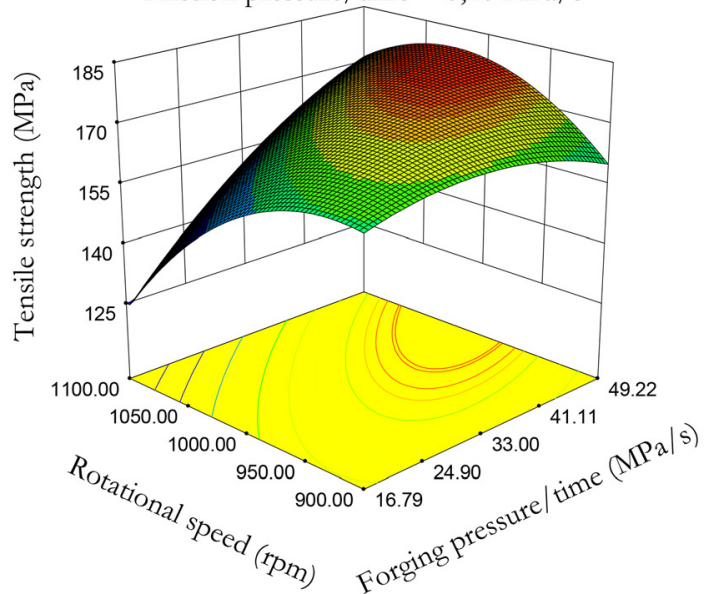

Micro-hardness:

$$
\begin{aligned}
M H= & 3310.9-275.6 A+28.71 B-5.26 C-2.14 A B \\
& +0.23 A C-0.02 B C+8.59 A^{2}+5.89 \times 10^{-3} B^{2} \\
& +2.18 \times 10^{-3} C^{2}
\end{aligned}
$$

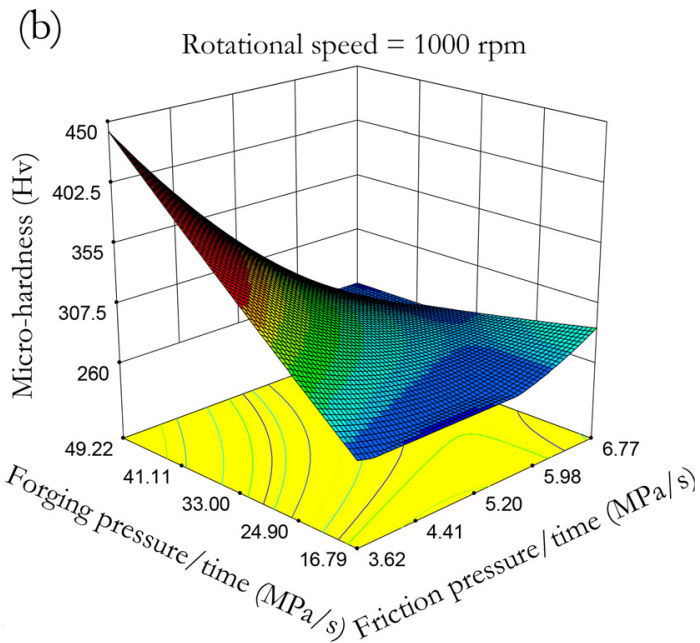

Forging pressure $/$ time $=33,01 \mathrm{MPa} / \mathrm{s}$
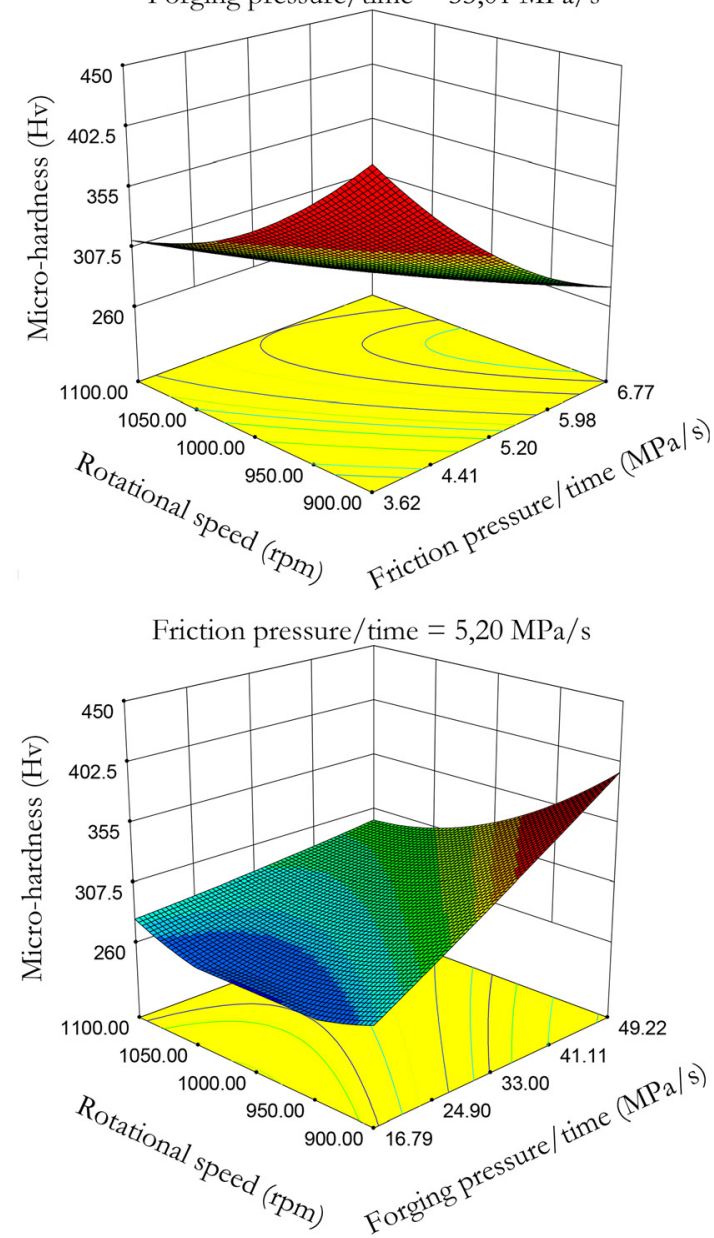

Figure 8. Response plots of welding parameters on: (a) tensile strength (TS); (b) Micro-hardness (MH) 


\subsubsection{Effect of welding parameters on the responses}

Effect of welding parameters on tensile strength (TS). The surface plots in Fig. 8a shows the interaction effect of each two input parameters on the response TS, while the third parameter is on its average level. The tensile strength of the welded joints increased with the increase of forging pressure/time and friction pressure/time, while the increase in rotational speed causes a decrease in tensile strength. By analyzing the response plots, the highest tensile strength value is $178.46 \mathrm{MPa}$, recorded from sample 8 which is prepared by forging pressure/time at the maximum level of 49.22 $\mathrm{MPa} / \mathrm{s}$.

The contribution rank of each welding parameters on tensile strength can be determined from their respective " $F$ Value" (Table 4), as the degrees of freedom are the same for all the input parameters $[21,30]$. The higher $F$ value implies that the respective parameter has more influence. From Table 4, it can be concluded that forging pressure/time contributes more to tensile strength and followed by friction pressure/time than the rotational speed.

Effect of welding parameters on micro-hardness (MH). The surface plots of response $\mathrm{MH}$ of joints is illustrated in Fig. 8 b. The hardness of the welded joints decreased with

Table 5. Optimization criteria used in this study

\begin{tabular}{|c|c|c|c|c|}
\hline \multirow{2}{*}{$\begin{array}{l}\text { Parameter and } \\
\text { responses }\end{array}$} & \multirow[b]{2}{*}{ Notation } & \multirow[b]{2}{*}{ Criterion } & \multicolumn{2}{|c|}{ Limit } \\
\hline & & & Lower & Upper \\
\hline $\begin{array}{l}\text { Friction pressure/ } \\
\text { time }(\mathrm{MPa} / \mathrm{s})\end{array}$ & $\mathrm{A}$ & Maximize & 3.62 & 6.77 \\
\hline $\begin{array}{c}\text { Forging pressure/ } \\
\text { time }(\mathrm{MPa} / \mathrm{s})\end{array}$ & B & Maximize & 16.79 & 49.22 \\
\hline $\begin{array}{l}\text { Rotational speed } \\
\quad(\mathrm{rpm})\end{array}$ & $\mathrm{C}$ & In range & 900 & 1,100 \\
\hline $\begin{array}{l}\text { Tensile strength } \\
\quad(\mathrm{MPa})\end{array}$ & TS & Maximize & 170 & 180 \\
\hline Micro-hardness (Hv) & $\mathrm{MH}$ & Maximize & 250 & 300 \\
\hline
\end{tabular}

increasing friction pressure/time and rotational speed. But the increase of forging pressure/time causes an increase in the hardness. The minimum hardness value is $253.5 \mathrm{Hv}$, corresponding to sample 7 , which is prepared at forging pressure/time minimum. From Table 4, the contribution rank of welding parameters is friction pressure/time followed by forging pressure/time than the rotational speed.

3.2.3. Optimization of welding parameters. The aim of this part is to find the optimum welding parameters to maximize both the strength and hardness of friction welded joints of AA 1100 to mild steel. The RSM is an ideal method for determination of these optimum welding parameters. The Optimization criteria were set as presented in Table 5, and the optimal solutions were shown in Table 6.

3.2.4. Validation of optimized solutions. In order to validate the optimized solutions provided by the previous model, three weld experiments were carried out according to the recommended parameters. Table 7 shows the optimum welding parameters, the measured and the predicted values of tensile strength and micro-hardness, and the percentage error. It can be concluded that there is an excellent agreement between measured values and predicted values.

\subsection{SEM and EDS analysis}

In order to show the effect of the forging pressure/time on the microstructure of the weld interface, SEM observations were performed on samples 7, 11 and 8. These samples are prepared under the same condition of rotational speed $(1,000 \mathrm{rpm})$ and friction pressure/time $(5.20 \mathrm{MPa} / \mathrm{s})$, but with different forging pressure/time. Figure 9 displays the SEM images of samples 7, 11 and 8. It is seen from Fig. 9a that a thin layer was formed at the weld interface of sample 7, which was prepared at the low value of forging pressure/ time $(16.79 \mathrm{MPa} / \mathrm{s})$. The thickness of this layer is $\sim 900 \mathrm{~nm}$. However, a very thin layer or no layer was formed at the weld interface of sample 11 (for an average value of forging pressure/time $33.01 \mathrm{MPa} / \mathrm{s}$ ) and sample 8 (at maximum

Table 6. Optimal solution as obtained by design-expert

\begin{tabular}{lcccccc}
\hline \multirow{2}{*}{ Solution } & \multicolumn{3}{c}{ Input parameters } & & \multicolumn{2}{c}{ Predicted values of results } \\
\cline { 2 - 4 } \cline { 3 - 5 } & $\mathrm{A}$ & $\mathrm{B}$ & $\mathrm{C}$ & & TS (MPa) & MH (Hv) \\
\hline 1 & 5.62 & 49.14 & 1001.25 & 180.00 & 300.00 \\
2 & 5.56 & 49.22 & 1009.70 & 180.48 & 300.00 & 0.8920 \\
3 & 5.84 & 49.22 & 992.55 & 179.02 & 291.50 \\
\hline
\end{tabular}

Table 7. Comparison between the predicted values and the experimental values

\begin{tabular}{|c|c|c|c|c|c|c|c|c|}
\hline \multicolumn{3}{|c|}{ Recommended parameters } & \multicolumn{3}{|c|}{ Tensile strength (MPa) } & \multicolumn{3}{|c|}{ Micro-hardness (Hv) } \\
\hline A & B & $\mathrm{C}$ & Exp. & Pred. & PE (\%) & Exp. & Pred. & PE (\%) \\
\hline 5.62 & 49.14 & 1001.25 & 178.36 & 180 & 0.91 & 312.5 & 300 & 4.17 \\
\hline 5.56 & 49.22 & 1009.70 & 170.28 & 180.48 & 5.65 & 289 & 300 & 3.67 \\
\hline 5.84 & 49.22 & 992.55 & 171.57 & 179.02 & 4.16 & 305 & 291.5 & 4.63 \\
\hline
\end{tabular}



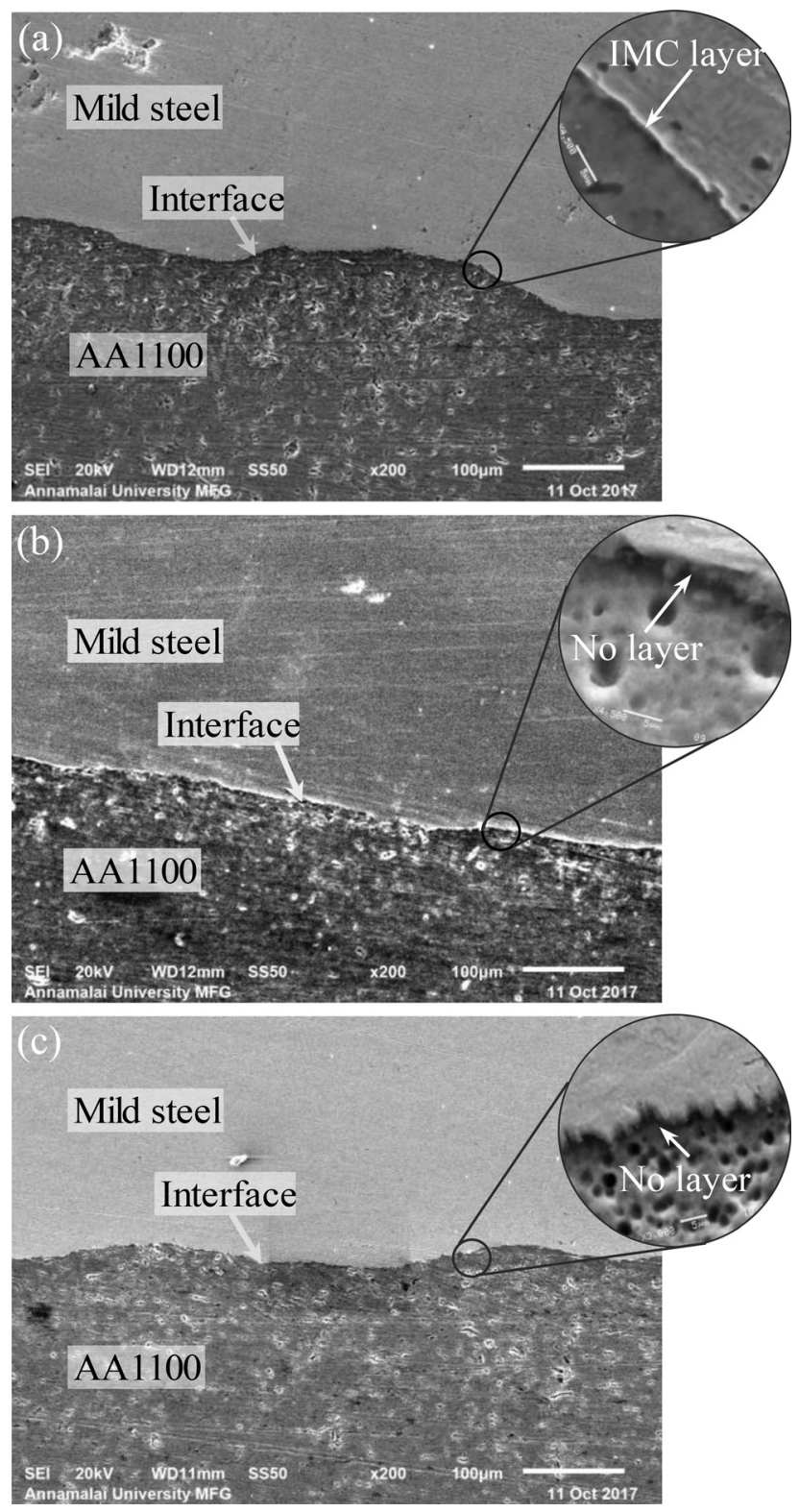

Figure 9. SEM images of the weld interface: (a) sample 7, (b) sample 11, (c) sample 8

value $49.22 \mathrm{MPa} / \mathrm{s})$. This means that the thickness of the IMC layer formed at the weld interface is decreased with increasing forging pressure/time.

In order to analyze the microstructure at the welding interface and investigate the existing phases, an EDS analysis was performed on a selected sample containing an IMC layer (Sample 7). Figure 10 shows the EDS analysis results of three regions $\mathrm{S}, \mathrm{I}$, and $\mathrm{A}$ corresponding respectively to the side of the mild steel, the interface region and the aluminum side. It can be seen that both Fe and $\mathrm{Al}$ elements were detected along the interface between the aluminum and the steel base materials which illustrates the presence of an IMC layer of Fe and $\mathrm{Al}$. The formation of this IMC layer at the weld interface of sample 7 may be the most probable reason for the weakness of its joint, whereas the disappearance of this layer increases the joint strength [31].

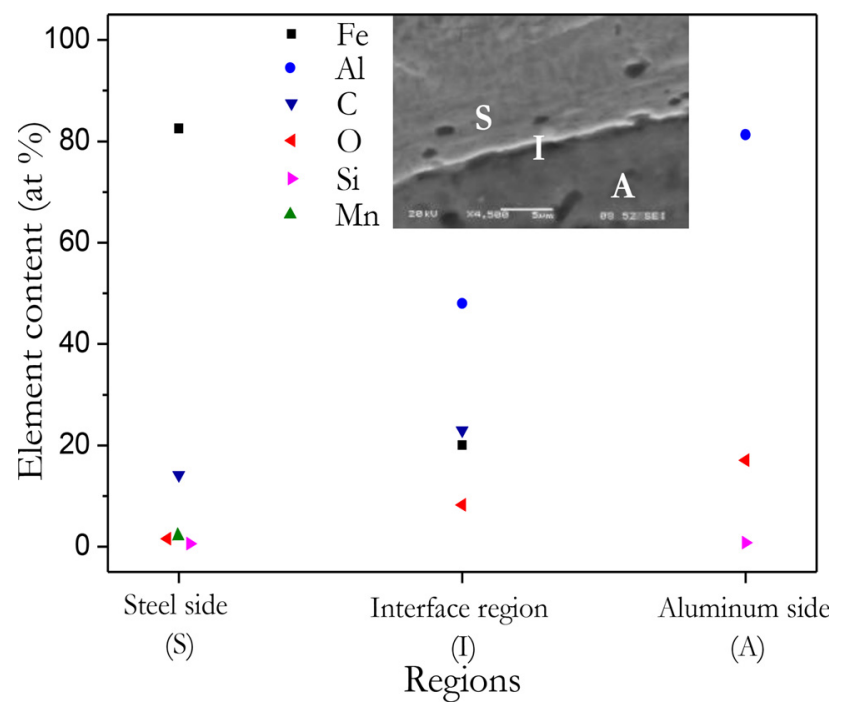

Figure 10. The EDS analysis results of sample (7)

\section{CONCLUSIONS}

Based on RSM - which is a collection of mathematical and statistical techniques used for designing the experiments an empirical relationship was developed to predict the tensile strength and hardness of friction welded AA1100 aluminum alloy and mild steel joints. This study led to the following results:

1. The empirical relationships developed can be effectively employed to predict the tensile strength and the hardness of friction welded joints.

2. The RSM analysis shows that the maximum strength of joints could be attained under the maximum level of forging pressure/time, while the minimum level product a minimum hardness in the weld joints.

3. The SEM observations revealed the formation of an IMC layer at the interface of some welds, which represents the most probable cause to justify the weakening of these joints.

\section{ACKNOWLEDGMENTS}

The authors thank the Algerian Research Organism DGRSDT for its financial support. The authors are grateful to Dr V. Balasubramanian, Director of CEMAJOR (Centre for Materials Joining and Research ) - Annamalai University - India, for extending the facilities of metal joining and material testing to carry out this work. The authors also acknowledge all CEMAJOR staff for their helpful assistance.

\section{REFERENCES}

[1] S. Fukumoto, H. Tsubakino, K. Okita, M. Aritoshi, and T. Tomita, "Amorphization by friction welding between 5052 aluminum alloy and 304 stainless steel.” Scripta Mater., vol. 42, pp. 807-812, 2000. 
[2] L. Agudo, D. Eyidi, C. H. Schmaranzer, E. Arenholz, N. Jank, J. Bruckner, and A. R. Pyzalla, "Intermetallic $\mathrm{Fe}_{\mathrm{x}} \mathrm{al}_{\mathrm{y}}$-Phases in a steel/ Al-alloy fusion weld.” J. Mater. Sci., vol. 42, pp. 4205-4214, 2007.

[3] S. Fukumoto, H. Tsubakino, K. Okita, M. Aritoshi, and T. Tomita, "Microstructure of friction weld interface of 1050 aluminium to austenitic stainless steel." Mater. Sci. Technol., vol. 14, pp. 333-338, 1998.

[4] W. B. Lee, Y. M. Yeo, D. U. Kim, and S. B. Jung, "Effect of friction welding parameters on mechanical and metallurgical properties of aluminium alloy 5052-A 36 steel joint.” Mater. Sci. Technol., vol. 19, pp. 773-778, 2003.

[5] M. Sahin, "Joining of aluminium and copper materials with friction welding." Int. J. Adv. Manuf. Technol., vol. 49, pp. 527-534, 2010.

[6] A. B. Dawood, S. I. Butt, G. Hussain, M. A. Siddiqui, A. Maqsood, and F. Zhang, "Thermal model of rotary friction welding for similar and dissimilar metals." Metals, vol. 7, pp. 1-14, 2017.

[7] B. S. Yilbas, A. Z. Sahin, A. Coban, and B. J. Abdul-Aleem, "Investigation into the properties of friction welded aluminum bars." J. Mater. Process. Technol., vol. 54, pp. 76-81, 1995.

[8] S. Celik, A. D. Karaoglan, and I. Ersozlu, "An effective approach based on response surface methodology for predicting friction welding parameters." High Temp. Mater. Process., vol. 35, pp. 235-241, 2015.

[9] S. T. Selvamani, K. Palanikumar, K. Umanath, and D. Jayaperumal, "Analysis of friction welding parameters on the mechanical metallurgical and chemical properties of AISI 1035 steel joints." Mater. Des., vol. 65, pp. 652-666, 2015.

[10] N. Özdemir, "Investigation of the mechanical properties of frictionwelded joints between AISI 304L and AISI 4340 steel as a function rotational speed.” Mater. Lett., vol. 59, pp. 2504-2509, 2005.

[11] W. Li, A. Vairis, M. Preuss, and T. Ma, "Linear and rotary friction welding review.” Int. Mater. Rev., vol. 61, pp. 71-100, 2016.

[12] A. Z. Sahin, B. S. Yilbas, and A. Z. Al-Garni, "Friction welding af Al-Al, Al-steel, and steel-steel samples." J. Mater. Eng. Perform., vol. 5, pp. 89-99, 1996.

[13] S. Fukumoto, T. Inuki, H. Tsubakino, K. Okita, M. Aritoshi, and T. Tomita, "Evaluation of friction weld interface of aluminum to austenitic stainless steel joint." Mater. Sci. Technol., vol. 13, pp. 679-686, 1997.

[14] S. Fukumoto, H. Tsubakino, K. Okita, M. Aritoshi, and T. Tomita, "Friction welding process of 5052 aluminum alloy to 304 stainless steel." Mater. Sci. Technol., vol. 15, pp. 1080-1086, 1999.

[15] M. Kimura, K. Suzuki, M. Kusaka, and K. Kaizu, "Effect of friction welding condition on joining phenomena, tensile strength, and bend ductility of friction welded joint between pure aluminium and AISI 304 stainless steel." J. Manuf. Process., vol. 26, pp. 178-187, 2017.

[16] M. Kimura, M. Kusaka, K. Kaizu, K. Nakata, and K. Nagatsuka, "Friction welding technique and joint properties of thin-walled pipe friction-welded joint between type 6063 aluminum alloy and AISI 304 austenitic stainless steel." Int. J. Adv. Manuf. Technol., vol. 82, pp. 489-499, 2016.

[17] M. Sahin, "Joining of stainless-steel and aluminum materials by friction welding." Int. J. Adv. Manuf. Technol., vol. 41, pp. 487497, 2009.
[18] E. P. Alves, F. P. Neto, and C. Y. An, "Welding of AA1050 aluminum with AISI 304 stainless steel by rotary friction welding process." J. Aero. Technol. Manag., vol. 2, pp. 301-306, 2010.

[19] S. D. Meshram and G. M. Reddy, "Friction welding of AA6061 to AISI 4340 using silver interlayer." Defence Technol., vol. 11, pp. 292-298, 2015.

[20] L. Wan and Y. Huang, "Friction welding of AA6061 to AISI 316L steel: characteristic analysis and novel design equipment." Int. J. Adv. Manuf. Technol., vol. 95, pp. 4117-4128, 2018.

[21] R. Paventhan, R. Lakshminarayanan, and V. Balasubramanian, "Prediction and optimization of friction welding parameters for joining aluminum alloy and stainless steel." Trans. Nonferrous Metals Soc. China, vol. 21, pp. 1480-1485, 2011.

[22] A. Pachal and A. Bagesar, "Taguchi optimization of process parameters in friction welding of 6061 aluminum alloy and 304 steel: a review." Int. J. Emerg. Technol. Adv. Eng., vol. 3, pp. 229-233, 2013.

[23] N. Mathiazhagan, T. S. Kumar, and M. Chandrasekar, "Optimization of friction welding parameters for AISI 304/AA6061 dissimilar metal joint using RSM/ANFIS.” Asian J. Res. Soc. Sci. Humanit., vol. 6, pp. 2089-2105, 2016.

[24] C. H. Lauro, R. B. D. Pereira, L.C. Brandao, L.C. Brandao, and J. P. Davim, "Design of experiments-statistical and artificial intelligence analysis for the improvement of machining processes: a review," in Design of Experiments in Production Engineering, Cham: Springer, pp. 89-107, 2016.

[25] R. H. Myers, D. C. Montgomery, and C. M. Anderson-Cook, Response Surface Methodology - Process and Product Optimization using Designed Experiment, 4th ed. New Jersey: John Wiley \& Sons, 2016.

[26] I. Dinaharan, N. Murugan, and A. Thangarasu, "Development of empirical relationships for prediction of mechanical and wear properties of AA6082 aluminum matrix composites produced using friction stir processing." Eng. Sci. Technol. Int. J., vol. 19, pp. 1132-1144, 2016.

[27] E. Raouache, N. Logzit, Z. Driss, and F. Khalfallah, "Optimization by RSM of reinforced concrete beam process parameters." Am. J. Mech. Eng., vol. 6, pp. 66-74, 2018.

[28] S. Rajakumar and V. Balasubramanian, "Microstructure and mechanical properties of electrical resistance spot welded interstitial free steel joints." J. Adv. Micros. Res., vol. 10, pp. 146154, 2015.

[29] P. Sammaiah, A. Suresh, and G. R. N. Tagore, "Mechanical properties of friction welded 6063 aluminum alloy and austenitic stainless steel." J. Mater. Sci., vol. 45, pp. 5512-5521, 2010.

[30] A. K. Lakshiminarayanan and V. Balasubramanian, "Comparison of RSM with ANN in predicting tensile strength of friction stir welded AA7039 aluminum alloy joints." Trans. Nonferrous Metals Soc. China, vol. 19, pp. 9-18, 2009.

[31] A. Ambroziak, M. Korzeniowski, P. Kustron, M. Winnicki, P. Sokolowski, and E. Harapinska, "Friction welding of aluminium and aluminium alloys with steel." Adv. Mater. Sci. Eng., vol. 2014, pp. 1-15, 2014.

\footnotetext{
Open Access statement. This is an open-access article distributed under the terms of the Creative Commons Attribution-NonCommercial 4.0 International License (https://creativecommons.org/licenses/by-nc/4.0/), which permits unrestricted use, distribution, and reproduction in any medium for non-commercial purposes, provided the original author and source are credited, a link to the CC License is provided, and changes - if any - are indicated.
} 